\title{
Purification and characterization of two killer toxins originated from Torulaspora delbrueckii (Lindner) and Wickerhamomyces anomalus (E.C.Hansen) Kurtzman, Robnett, and Basehoar-Powers
}

\author{
Najwa Mohammed Jameel Ali Abu-Mejdad ${ }^{1 *}$, Adnan I. Al-Badran ${ }^{1}$ and Abdullah H. Al-Saadoon²
}

\begin{abstract}
Background: Ecological killer yeasts have had few studies compared with laboratory killer yeasts. The killer yeasts are known in excreting killer toxins that kill sensitive or susceptible yeasts. The killer toxins, such as TK and WK excreted from two yeast isolates (Torulaspora delbrueckii and Wickerhamomyces anomalus) have protenious nature with different molecular weight depending on yeast species.

Results: A qualitative test was conducted to determine the ability of both isolates to produce killer toxins on the media of yeast extract and malt extract broth when the two toxins were first purified by ammonium sulfate salt at $40 \%$ concentration and then by dialysis for the killer toxin TK and gel filtration method for WK. The molecular weight of TK was estimated at about $15 \mathrm{kDa}$, while WK was at $45 \mathrm{kDa}$. The chemical properties of the killer toxins were also studied. The results showed that the two killer toxins were with protenious nature.

Conclusion: Both yeast isolates (Torulaspora delbrueckii and Wickerhamomyces anomalus) had the ability of producing different kinds of killer toxins. The two killer toxins (TK and WK) were identified for the first time in Iraq, and their production involves many steps of economically unexpansive purification method with a good quality and high purity of producing killer toxins. The results confirmed that the nature of killer toxins (WK and TK) was similar to protein compounds resulted from the transition in UV and functional groups.
\end{abstract}

Keywords: Killer toxins, Protein, Torulaspora delbrueckii, Wickerhamomyces anomalus

\section{Introduction}

Killer yeasts are known in excreting killer toxins that kill sensitive or susceptible yeasts (Becker and Schmitt 2017). After the first report that indicated, the killer yeasts have antibacterial abilities, numerous antibacterial proteins initiating from yeasts have been recognized and considered as killer toxins. For instance, the Kx killer toxin secreted by Saccharomyces cerevisiae is protein

\footnotetext{
* Correspondence: najwajameel78@yahoo.com

'Department of Biology, College of Science, University of Basrah, Basrah, Iraq Full list of author information is available at the end of the article
}

with molecular weight (45 KDa) (Melvydas et al. 2016). Also, the killer toxin excreted from Candida kruseii, isolated from fermented vegetables, displayed growth inhibition against Escherichia coli, Staphylococcus aureus, Salmonella enterica serotype typhimurum, and Bacilluscereus (Waema et al. 2009). Furthermore, S. cerevisiae has been reported having a killer activity against some bacterial strains (Valzano et al. 2016).

In addition to, Al-Qaysi et al. (Al-Qaysi et al. 2017) have recently demonstrated that the killer toxin originated from Debaryomyces hansenii DSMZ70238 have an ability of killing several bacteria, such as S. aureus, 
E. coli, Klebsiella pneumoniae, and Streptococcus pyogenes. According to Liu et al. (Liu et al. 2015), Ascomycetous yeast species are particularly attractive targets producing killer toxins like proteins, because such organisms are known in producing a large variety of secondary metabolites and extracellular enzymes that have a medical importance as alternative drugs for bacterial resistant strains, especially MRD (multi resistance drugs). Regarding the characteristics required to conduct alcoholic fermentation in industry for the non-Saccharomyces yeasts such as T. delbrueckii and W.anomalus that are identical to the referent, best-deemed, $S$. cerevisiae. This is why $T$. delbrueckii and $W$. anomalus have been taken as the first non-Saccharomyces yeast suggested for industrial implementation in wine fermentation (Mauricio et al. 1998). However, small but pertinent dissimilarities in the physiological features of the two yeasts influence their option as selects for various industrial applications. In specific, the particular production range of killer toxin and raise alcoholic fermentation range by eliminated un coveted yeast by killer yeast that generated killer toxins to kill such yeast (Coda et al. 2011). As a result based on this background, the authors of this study were searching for killer toxins originated from ascomycetous yeasts in soil by using two type strains (Torulaspora delbrueckii and Wickerhamomyces anomalus) as examined strains. Accordingly, the isolation, purification, and some properties of two killer toxins were described. The killer toxins produced by $T$. delbrueckii and $W$. anomalus were called TK and WK respectively.

\section{Material and methods Yeast strains}

The killer yeast strains Torulaspora delbrueckii and Wickerhamomyces anomalus were isolated from soilBasrah (Abu-Alkhaseeb and Al-Qurna)-Iraq.

\section{Culture media}

Yeast malt extract broth (YMB) with 1\% SDS: yeast extract $3 \mathrm{~g}$, malt extract $3 \mathrm{~g}$, peptone $5 \mathrm{~g}$, glucose $10 \mathrm{~g}$, SDS $2 \mathrm{~g}$, distilled water $1000 \mathrm{ml}$ (Jorgensen et al. 2015); nutrient agar (Himedia, India) for antibacterial activity and activation of pathogenic bacteria, potato dextrose agar (Oxoid, UK) for the activation of yeast isolates.

\section{Purification of killer toxins (TK, WK) Fermentation medium}

During this study, the best fermentation conditions were selected (medium of producing killer toxins), which is the medium of yeast malt extract broth (YMB) (Jorgensen et al. 2015) added to it is sodium dodecyl sulfate $0.2 \%$ (SDS) with the optimum conditions $30 \mathrm{C}^{\circ}$ for $3-5$ days and rotated at $150 \mathrm{rpm}$.

\section{Protein purification}

\section{Precipitation with ammonium sulfate salt}

The precipitation total protein with ammonium sulfate salts at the concentration of $40 \%$ weight/volume (saturation ratio) of the crude protein extracted from the best liquid fermentation culture filtrate for two isolates Torulaspora delbrueckii and Wickerhamomyces anomalus after the elimination of the yeast cells by centrifugation at $6000 \mathrm{rpm} / \mathrm{min}$ for $20 \mathrm{~min}$. Salt was added gradually with continuous stirring. After complete dissolving, the solution was left for an hour at $4 \mathrm{C}^{\circ}$. For the purpose of obtaining the crude protein, the solution was centrifuged with the high-speed centrifuge $(10,000 \mathrm{rpm} / \mathrm{min}$ for 10 min) modify in time and number of round per minute of centrifuge (Taguchi 1995).

\section{Dialysis}

The crude protein precipitate which was weighed $4.1 \mathrm{~g}$ for Torulaspora delbrueckii, obtained from the above stage was dissolved with $125 \mathrm{~mL}$ of the buffer solution (citrate buffer), $(\mathrm{pH}=4.4)$ for the dialysis process using special dialysis bags to this purpose using $(3,10) \mathrm{KDa}$

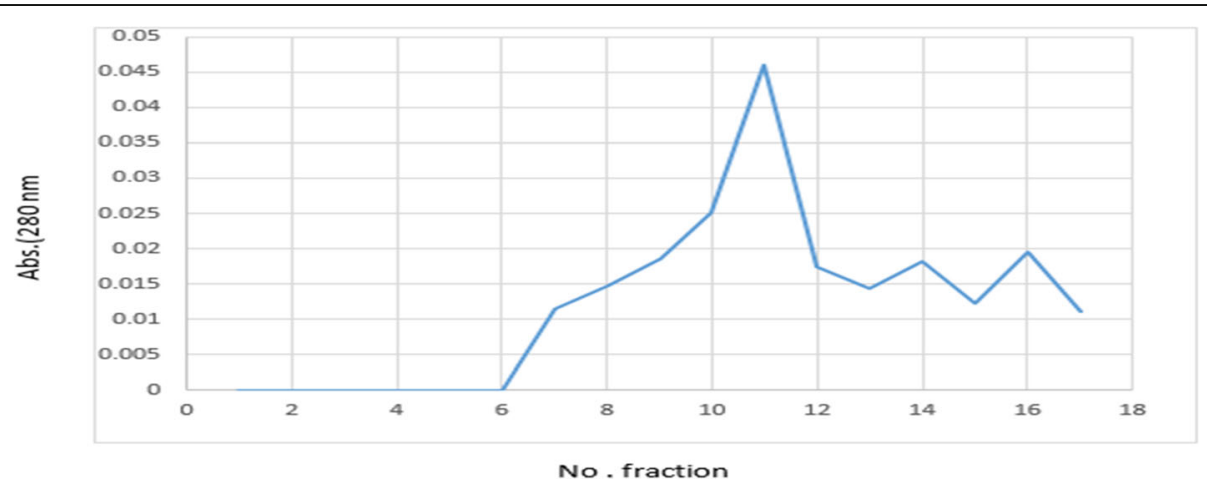

Fig. 1 Absorbance values of proteins content for purification killer toxin of Wickerhamomyces anomalus (WK) 
Table 1 Summary of the purification procedure of killer toxin from Torulaspora delbrueckii

\begin{tabular}{lllllll}
\hline Stage & Volume $(\mathrm{ml})$ & $\begin{array}{l}\text { Protein concentration } \\
(\mathrm{mg} / \mathrm{ml})\end{array}$ & $\begin{array}{l}\text { Specific activity } \\
(\mathrm{U} / \mathrm{mg})\end{array}$ & Total activity $(\mathrm{U})$ & $\begin{array}{l}\text { Purification factor } \\
(\text { fold })\end{array}$ & $\begin{array}{l}\text { Yield \% } \\
\text { Culture supernatant }\end{array}$ \\
Ammonium sulfate precipitation & 900 & 5 & 6 & 27,000 & 1 & 100 \\
Dialysis & 125 & 4.1 & 6.8 & 3500 & 1.133 & 12.9 \\
\hline
\end{tabular}

dialysis bags. The process of dialysis was done at $4{ }^{\circ} \mathrm{C}$ for $48 \mathrm{~h}$ with dialysis solution (distilled water) changed almost every $12 \mathrm{~h}$. The size of the protein extract was estimated with milliliter, and its protein concentration was estimated, then lyophilization is the purified protein, preserved it for biological activity.

Note: The purify of the protein was checked by using vertical electrophoresis SDS-PAGE. Purification of killer toxins from Wickerhamomyces anomalus by sephadex G-LH 20 (Villalba et al. 2016).

\section{Fractionation of protein extract on G-20 sephadex}

The gel chromatography was used for purification of protein extract into molecular size according to the method of Taguchi (1995) with modification as follows:

- Sephadex G-20 $2 \mathrm{~g}$ dry weight was activated in about $50 \mathrm{ml}$ of ice methanol for $15 \mathrm{~min}$ to provide gel for a $(1 \times 15) \mathrm{cm}$ column.

- Sodium azide was added to column (NaN3) to prevent contamination; the gel was left after pouring in the column for $18 \mathrm{~h}$ to the purpose of stabilization and stacking, and then wash the gel by methanol.

- Void volume (Vo) using the blue Dextran 2000 KDa dye at $0.01 \mathrm{~g} / \mathrm{ml}$ concentration.

Measuring of protein concentration in purified killer toxin The protein concentration of purified killer toxin was measured after pooling the tubes that form each peak together, the measurement was carried out using Lowry method. The Lowry protein assay is a biochemical test for defining the level of total protein in a solution. The concentration of total protein is displayed by the changes of sample solution color in ratio to the concentration of protein concentration that can be calculated using colorimetric techniques with using bovine serum albumin (BSA) as a standard protein with graduate concentrations (100 to $1000 \mu \mathrm{g} / \mathrm{ml}$ ) (Lowery et al. 1951).

\section{Polyacrylamide gel electrophoresis}

The procedure according to the principle of (Laemmli 1970), SDS-PAGE depends on the separation of proteins and their molecular weight. In the present study, $12 \%$ resolving gel was made for analysis, $(0.025 \mathrm{M}$ Tris, $0.25 \mathrm{M}$ glycine, $0.1 \%$ SDS) for $1 \times$ tank buffer for SDS-PAGE. The protein samples to be analyzed were loaded into the wells formed in the resolving gel with a fine tip. The samples were electrophoresed for $60 \mathrm{~min}$ at 80 volts then the voltage was increased to 100 volts for another 60 min. Coomassie blue was used for staining polyacrylamide gels after electrophoresis to visualize the resolved protein bands, destain solution is prepared as follows: methanol $10 \mathrm{ml}$, glacial acetic acid $10 \mathrm{ml}$, D.W. $80 \mathrm{ml}$.

\section{Biological activity of purified killer toxins extracted as antifungal}

The susceptibility test of the purified toxins was performed as described in (Al-Hilfy and Abu-Mejdad 2014), A $100 \mu \mathrm{l}$ from the suspension of Candida albicans which obtained it from Al-Zubair Hospital, patient suffering from cutaneous candidiasis and identifying it by ITS15.8rRNA-ITS2 in mycological lab, then added suspension of yeast to the Sabourauds agar, spread it by Lshaped glass spreader. The plates were left to dry for 15 min at room temperature and then wells with $6 \mathrm{~mm}$ diameter were made using cork-borer. After that, a $100 \mu \mathrm{l}$ of killer toxins (TK, WK) at concentration of 200 $\mathrm{mg} / \mathrm{ml}, \mathrm{DW}$ were added individually to each well and incubated at $37 \mathrm{C}^{\circ}$ for $24 \mathrm{~h}$. The results were read by measuring the inhibition zone diameter in millimeter.

Table 2 Summary of the purification procedure of killer toxin from Wickerhamomyces anomalus

\begin{tabular}{lllllll}
\hline Stage & Volume $(\mathrm{ml})$ & $\begin{array}{l}\text { Protein concentration } \\
(\mathrm{mg} / \mathrm{ml})\end{array}$ & $\begin{array}{l}\text { Specific activity } \\
(\mathrm{U} / \mathrm{mg})\end{array}$ & Total activity (U) & Purification factor (fold) & Yield \% \\
\hline Culture supernant & 900 & 5.3 & 6.6 & 31,500 & 1 & 100 \\
Ammonium sulfate precipitation & 125 & 3.9 & 7.6 & 3750 & 1.151 & 11.90 \\
Sephadex LH-G20 & 8 & 0.02 & 1750 & 280 & 230 & 0.88 \\
\hline
\end{tabular}




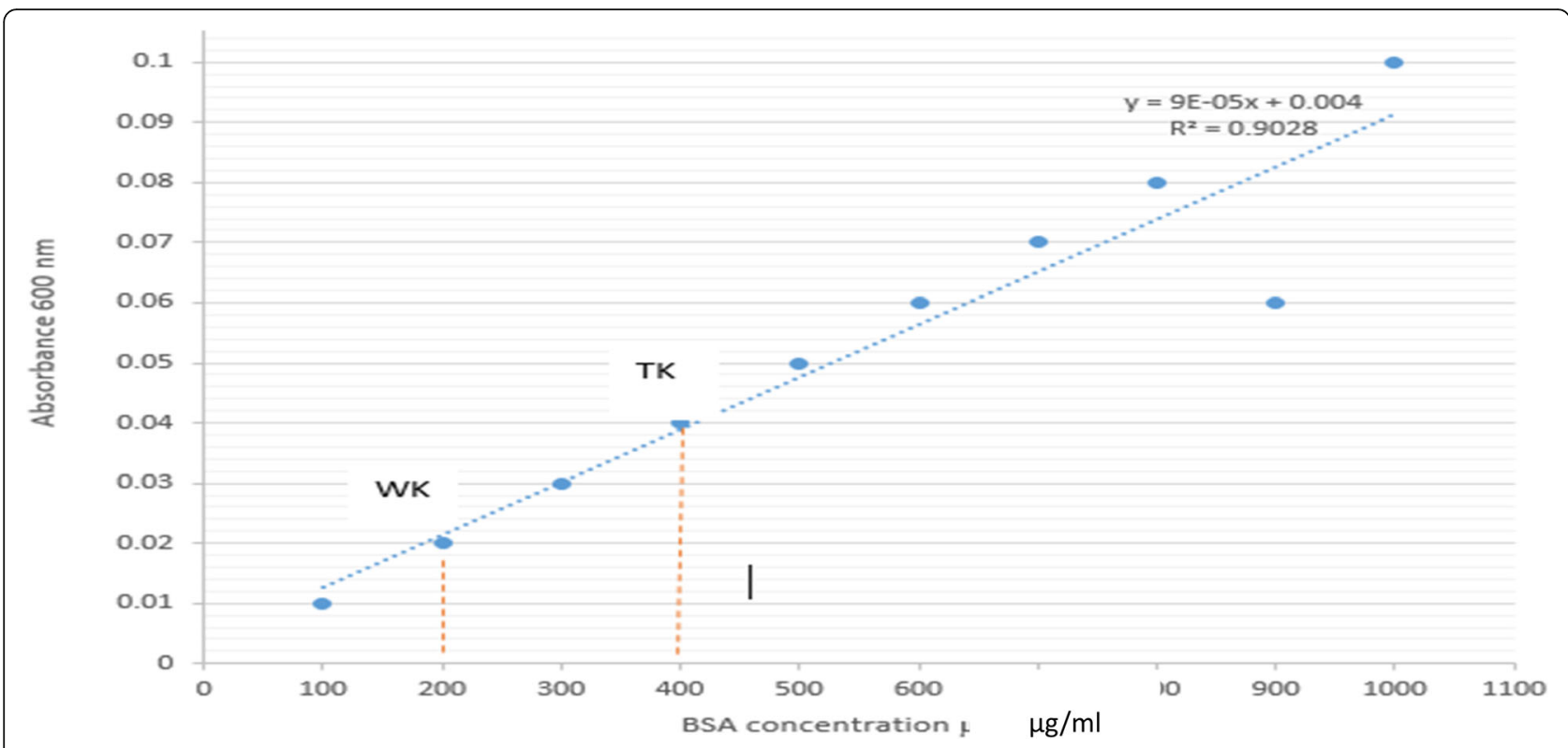

Fig. 2 Standard curve for Lowry method. The curve was made using bovine serum albumin (BSA) as a standard protein with graduate concentrations (100 to $1000 \mathrm{\mu g} / \mathrm{ml})$. TK represents the concentration of $0.04 \mathrm{mg} / \mathrm{ml}$ value and WK represents the concentration of $0.02 \mathrm{mg} / \mathrm{ml}$ value

\section{IR spectrum for killer toxins}

These were measured using the FTIR spectra ( $\mathrm{KBr}$ discs) that were recorded in the $4000-500 \mathrm{~cm}^{-1}$ range on a Shimadzu IRAffinity-1 spectrometer. This was processed at the Department of ChemistrylCollege of Science, University of Dhi Qar.

\section{UV absorbance spectroscopy}

UV absorption spectra for killer toxins were recorded in an aqueous solution $\left(0.1 \mathrm{~g} / 10 \mathrm{ml} \mathrm{H}_{2} \mathrm{O}\right)$ on a PG T90U UV-visible spectrophotometer using conventional quartz cell having an optical path length of $1 \mathrm{~cm}$ at $298 \mathrm{~K}$. This was processed at the Department of Chemistry $\backslash$ College of Science, University of Dhi Qar (Silverstein et al. 1991).

\section{Results}

Purification of killer toxin for Wickerhamomyces anomalus by gel chromatography using sephadex LH-G20

Figure 1 shows the presence of 3 protein peaks resulted from the gel chromatography by using sephadex LH-G20 of the killer toxin. When testing, the individual antifungal activity of each part of these protein peaks, only the first peak was contained the killer toxin (WK), while the other peaks were not showing any biological activity. This indicates that the killer toxin (WK) was fully separated at the first peak, and the toxin had a high molecular weight compared to the rest of other separated proteins. The biological activity was determined against Candida albicans at $35 \mathrm{~mm}$ and the specific activity 1750 units/mg with factor fold 230 and protein yield of $0.88 \%$ (Tables 1 and 2).

\section{Determination of protein concentration in two compounds (TK, WK)}

The protein concentration of killer toxin was determined in Torulaspora delbrueckii and Wickerhamomyces anomalus. The first compound (TK) was containing $0.04 \mathrm{mg} / \mathrm{ml}$, while the later (WK) had only $0.02 \mathrm{mg} / \mathrm{ml}$ depended on bovine serum albumin standard curve (Fig. 2). This

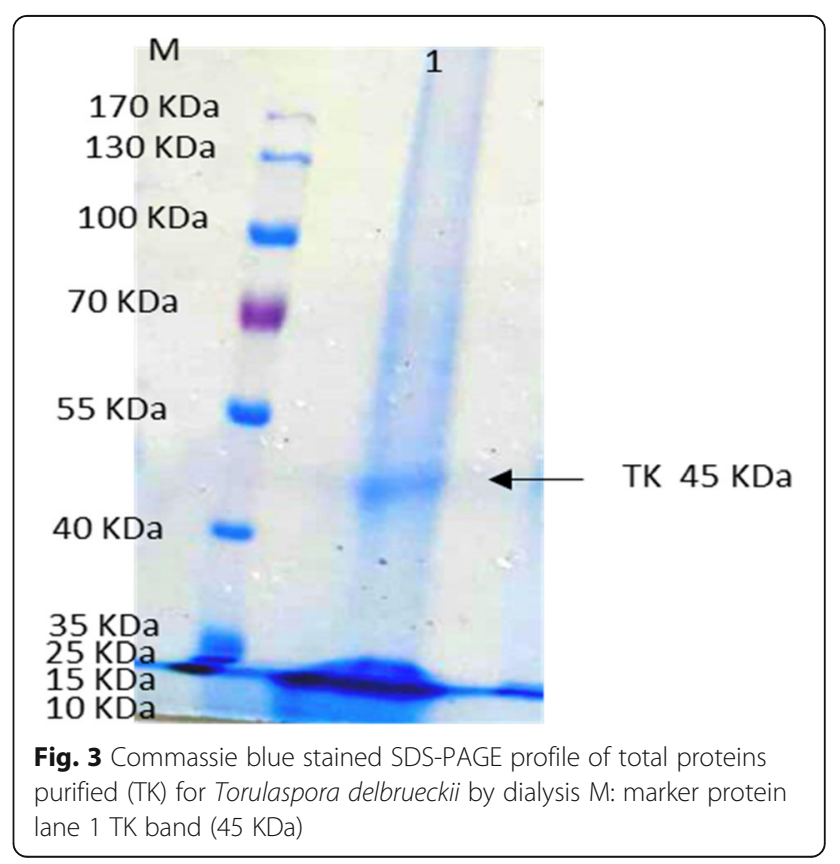


1

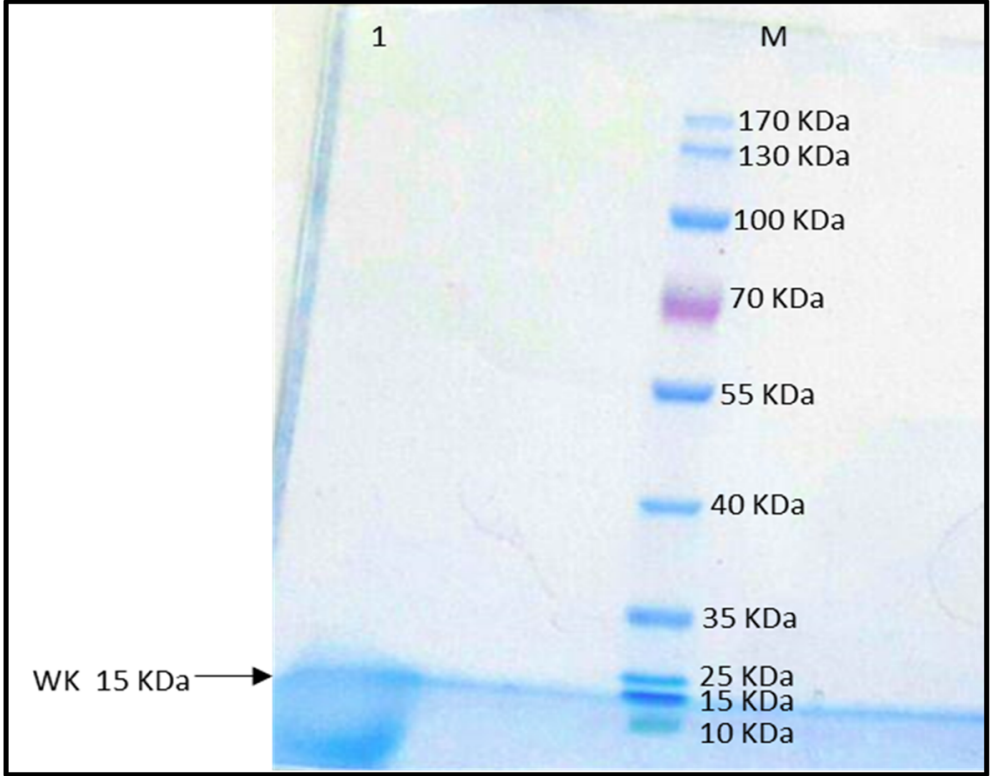

Fig. 4 Commassie blue stained SDS-PAGE profile of total proteins purified (WK) for Wickerhamomyces anomalus by ion exchange chromatography using L-H sephadex M: Marker protein lane 1 WK $(15 \mathrm{KDa})$ band

clarified the concentration and amount of TK was more than WK after purification of each them individually.

\section{SDS-PAGE}

The results of the analysis of purified proteins on SDSPAGE $12 \%$ were shown sharp bands (WK) for Wickerhamomyces anomalus at $15 \mathrm{KDa}$ (expected size) compared with Ladder. Figure 3 and the results shown (TK) for Torulaspora delbrueckii presence of $\sim 45 \mathrm{KDa}$ (expected size) band compared with Ladder (Fig. 4).

\section{UV absorption spectroscopy of TK and WK killer toxins}

Figures 5 and 6 show the UV absorption spectra in distilled water. One strong absorption bands at lower wavelengths appeared $237 \mathrm{~nm}$ for TK UV, while two strong absorption bands at lower wavelengths appeared within 229-264 nm for WK UV. These absorption bands correspond to $\pi-\pi^{*}$ transitions that appear due to groups like $\mathrm{O}-\mathrm{H}$ and $\mathrm{N}-\mathrm{H}$. At longer wavelengths, the absorption spectra showed weak third bands within 283 in TK UV , $317 \mathrm{~nm}$ in WK UV which could be correlated to $\mathrm{n}-\pi^{*}$ transitions that appear due to groups like $\mathrm{O}-\mathrm{H}$ and $\mathrm{N}-\mathrm{H}$.

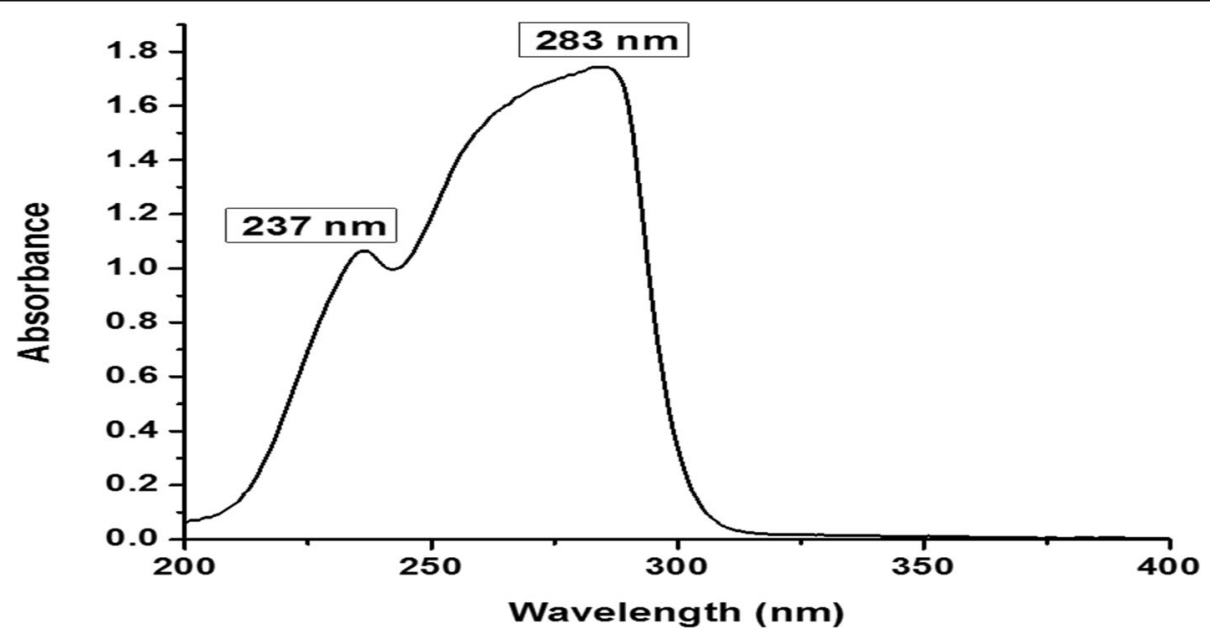

Fig. 5 UV absorption spectrum of killer toxins for Torulaspora delbrueckii (TK) toxin ( $10 \mathrm{mg} / \mathrm{ml} \mathrm{H2O}$ ) using UV-visible quartz cell with path length of $1 \mathrm{~cm}$ at $298 \mathrm{~K}$ 


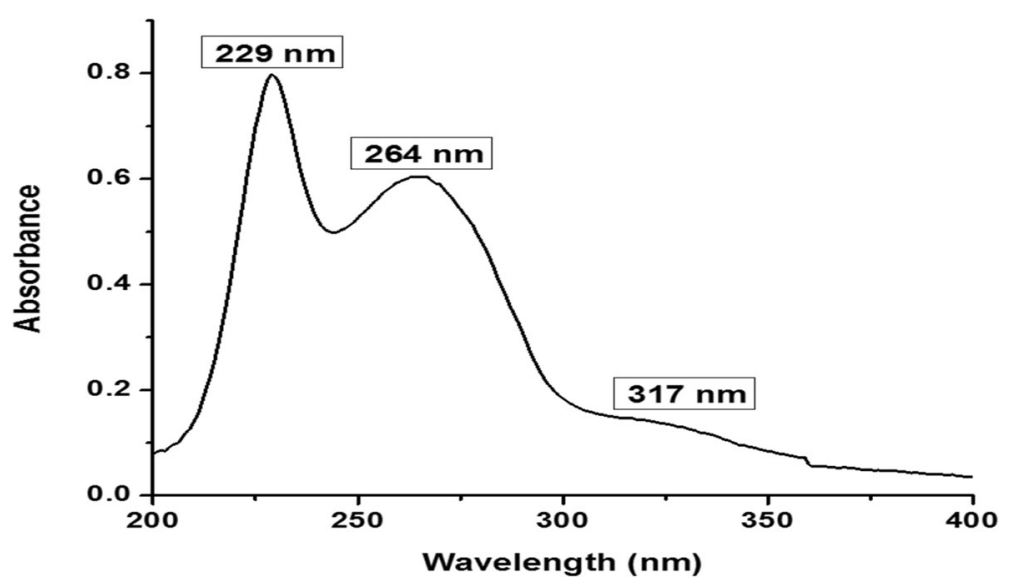

Fig. 6 UV absorption spectrum of killer toxins for Wickerhamomyces anomalus (WK) toxin (10 mg/ml H2O) using UV-visible quartz cell with path length of $1 \mathrm{~cm}$ at $298 \mathrm{~K}$

\section{FT-IR of killer toxins}

The structure of KT and WK were characterized by FTIR spectroscopy. The FTIR spectra and their assignments are shown in Figs. 7 and 8 and Tables 3 and 4 respectively

\section{Discussion}

\section{Purifying killer toxins from two isolates}

\section{(Wickerhamomyces anomalus and Torulaspora delbrueckii)}

The results of killer toxin purification from two yeast strains (Wickerhamomyces anomalus and Torulaspora delbrueckii) showed that there was a high increase in the specific activity of killer toxins after each stage of purification Tables 1 and 2. This can be reasoned to the specific activity of each toxin in the first stage of purification for both strains, which were precipitated with ammonium sulfate, then removing the suspended impurities with the protein substance (killer toxins), concentrated in precipitation and converted to a nonsoluble substance to increase their specific activities (Nooralabettu 2014).
In the second stage of purification of Torulaspora delbrueckii, increasing specific activities were observed to be high and significant in the killer toxin because of the removal role of salt.

In terms of Wickerhamomyces anomalus, the isolation of toxin was purified at the first stage, while in the second stage, the method of purification was different as gel filtration chromatography by L-H G20 was used. This technique provided a good separation of protein compounds and purification based on their molecular weight and shape (Mohan et al. 2018). Figure 1 shows that the first peak represents a significant biological activity due to the presence of pure killer toxin in a good specific activity compared to the crude extract in several steps mentioned in the current study as well as the number of high purification factors was doubled.

\section{Molecular weight estimation SDS-PAGE}

Gomes et al. (Nooralabettu 2014) confirmed that the differences in molecular weights of different yeast proteins resulted from the differences in genetics and controlling

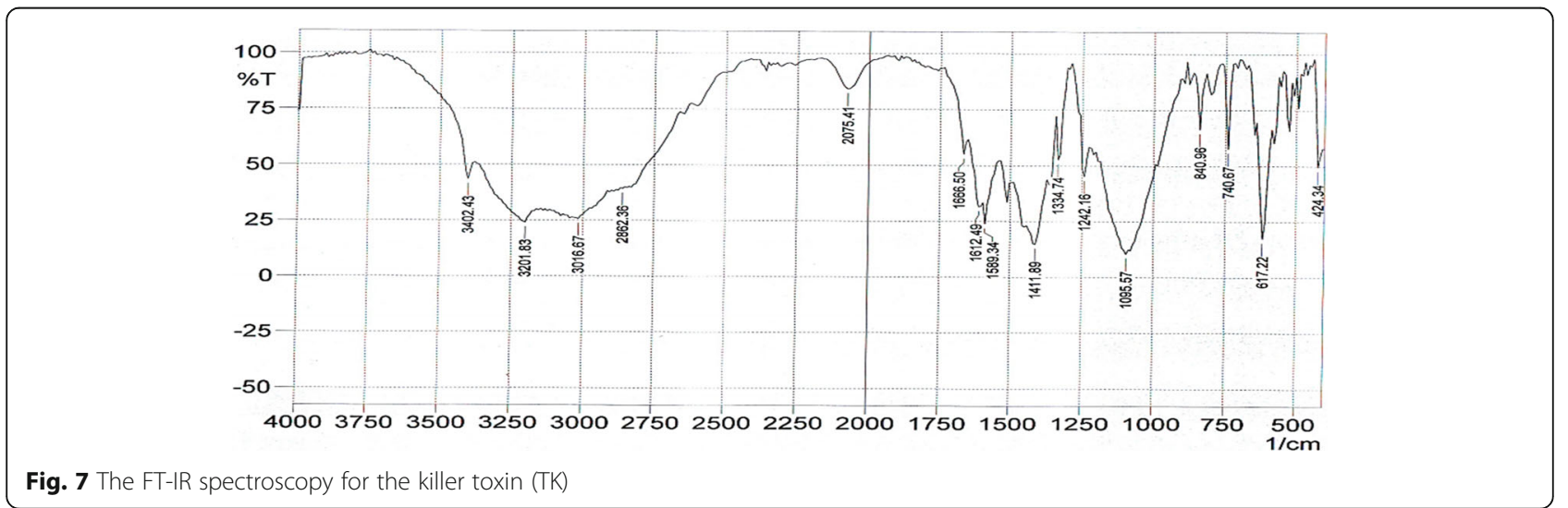




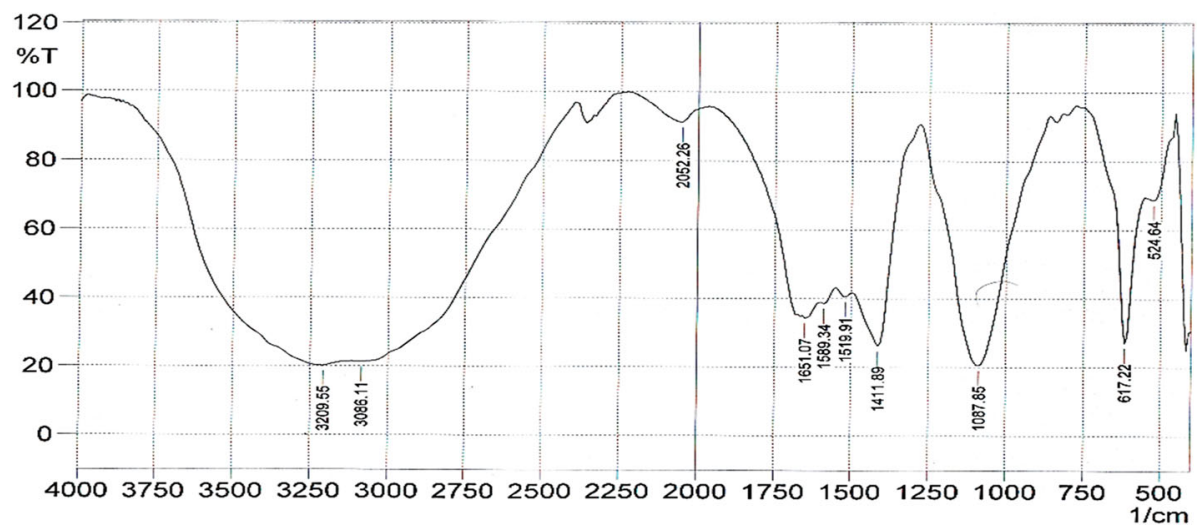

Fig. 8 FT-IR spectroscopy for the killer toxin (WK)

genes on the formation of these proteins in their yeast. The current work compared the two yeast species $(S$. cerevisiae and Saccharomyces paradoxus) and stated an excess of directional influence of translation. An mRNA dissimilarities between species was typically associated with the variation in translation in the obverse direction, leading to different protein production and its molecular weight (McManus et al. 2014). The molecular weight of Wickerhamomyces anomalus (WK) was estimated in this study to be found in 15 by using SDS-PAGE technique (Fig. 4).

According to Giselle and Hélia (Soares and Sato 2000), the molecular weight of killer toxins varies among yeast strains. For example, the molecular weights of killer toxins from different yeast genera was ranging between $18-300 \mathrm{kDa}$. In the current study, the molecular weight of killer toxin in the strain 28 (KT28) of S. cerevisiae was measured at $16 \mathrm{kDa}$, which is conformed to the findings revealed in the above study. Therefore, it can be stated that this protein may be a type of K28. Proteins isolated from the two fungi Torulaspora delbrueckii (TK) and Saccharomyces cerevisiae had molecular weights of 45

Table 3 The FT-IR functional groups of purified TK

\begin{tabular}{ll}
\hline Wave number $\left(\mathrm{cm}^{-1}\right)$ & Assignment \\
\hline 3402.43 & $\mathrm{~N}-\mathrm{H}$ stretching \\
3201.83 & O-H stretching \\
3016.67 & Alkene C-H stretching \\
2862.36 & Aliphatic C-H stretching \\
$1666.50,1612.49$, & C=O stretching, C=C stretching and N-H \\
1589.34 & bending \\
1441.89 & O-H bending and C-N stretching (superimposed \\
1095.57 & bands) \\
617.22 & C-O stretching \\
\hline
\end{tabular}

and 38.7 KD respectively, which maybe reasoned to the different type of isolates that their killer toxins produced under approved variation and measurement techniques in different studies. So, through the convergence of two proteins brought this protein back to the $\mathrm{K} 2$ type, which was isolated by gel filtration chromatography (G-75), (Mehlomakulu 2015).

\section{UV and FTIR analysis}

The results confirmed that the nature of killer toxins (WK and TK) was similar to proteins compounds resulted from the transition in UV and functional groups (T.R. S 2009).

\section{Conclusion}

Killer yeasts are known in excreting killer toxins that kill sensitive or susceptible yeasts. Both isolates (Torulaspora delbrueckii and Wickerhamomyces anomalus) have the ability to produce different types of killer toxins, when growing in suitable fermentation medium with high production efficiency. The killer toxins (TK, WK) have been identified for the first time in Iraq, and their production involved many steps of economically unexpansive

Table 4 The FT-IR functional groups of purified WK

\begin{tabular}{|c|c|}
\hline Wave number $\left(\mathrm{cm}^{-1}\right)$ & Assignment \\
\hline 3209.55 & $\begin{array}{l}\mathrm{N}-\mathrm{H} \text { stretching and } \mathrm{O}-\mathrm{H} \text { stretching } \\
\text { (superimposed bonds) }\end{array}$ \\
\hline 3086.11 & Alkene $\mathrm{C}-\mathrm{H}$ stretching \\
\hline $\begin{array}{l}\text { 1651.07, 1589.34, } \\
1514.91\end{array}$ & $\begin{array}{l}\mathrm{C}=\mathrm{O} \text { stretching, } \mathrm{C}=\mathrm{C} \text { stretching and } \\
\mathrm{N}-\mathrm{H} \text { bending }\end{array}$ \\
\hline 1411.89 & $\begin{array}{l}\text { O-H bending and C-N stretching (superimposed } \\
\text { bands) }\end{array}$ \\
\hline 1087.85 & C-O stretching \\
\hline 617.22 & Alkene $\mathrm{C}-\mathrm{H}$ bending \\
\hline
\end{tabular}


purification method to produce killer toxins with good quality and high purity. The sequences of purified killer toxin have been deposited in the Genbank. The use of developed chemical method has confirmed the determination of crystalized structure of the isolated proteins.

\section{Abbreviations}

cm: Centimeter; $C^{\circ}$ : Centigrade; FT-IR: Fourier transforms infrared; g: Gram; KBr: Potassium bromide; KDa: Kilo dalton; Min: Minutes; MRD: Multi resistance drugs; PAGE: Polyacrylamide gel electrophoresis; pH: Power of hydrogen; rpm: Round per minute; SDS: Sodium dodecyl sulfate; Sephadex G-LH 20: Sephadex gel- LH20; TK: Torulaspora delbrueckii killer toxin; UV: Ultraviolet; WK: Wickerhamomyces anomalus killer toxin; YMB: Yeast malt extract broth

\section{Acknowledgements}

Not applicable in this section.

\section{Authors' contributions}

All work was done by NA under supervision and advice of AA and AA. NA was a major contributor in writing the manuscript. All authors read and approved the final manuscript.

\section{Funding}

Not applicable in this section.

\section{Availability of data and materials}

Not applicable in this section.

\section{Ethics approval and consent to participate}

Not applicable in this section.

\section{Consent for publication}

Not applicable in this section.

\section{Competing interests}

The authors declare that they have no competing interests in this section.

\section{Author details}

'Department of Biology, College of Science, University of Basrah, Basrah, Iraq. ${ }^{2}$ Department of Pathological Analyses, College of Science, University of Basrah, Basrah, Iraq.

Received: 30 January 2020 Accepted: 24 March 2020

Published online: 06 April 2020

\section{References}

Al-Hilfy AA, Abu-Mejdad NM (2014) Evaluate the Activity Antifungal of Aspirin In Mice Balb/C infected with Candida albicans In vitro and In vivo. Res J Pharm, Biol Chem Sci 5(3):1714-1728

Al-Qaysi SA, Al-Haideri H, Thabit ZA, Al-Kubaisy WHA, Ibrahim JAA (2017) Production, characterization, and antimicrobial activity of mycocin produced by Debaryomyces hansenii DSMZ70238. International journal of microbiology 2017

Becker B, Schmitt MJ (2017) Yeast killer toxin K28: biology and unique strategy of host cell intoxication and killing. Toxins. 9(10):333

Coda R, Cassone A, Rizzello CG, Nionelli L, Cardinali G, Gobbetti M (2011) Antifungal activity of Wickerhamomyces anomalus and Lactobacillus plantarum during sourdough fermentation: identification of novel compounds and long-term effect during storage of wheat bread. Appl Environ Microbiol 77(10):3484-3492

Jorgensen J, Pfaller MA, Carroll KC, Funke G, Landry ML, Richter SS, Warnock DW (2015) Manual of Clinical Microbiology, Eleventh Edition. Mycoses 40(7-8): 313-315

Laemmli UK (1970) Cleavage of structural proteins during the assembly of the head of bacteriophage T4. Nature. 227:680-685

Liu G, Chi Z, Wang G, Wang Z, Li Y, Chi Z (2015) Yeast killer toxins, molecular mechanisms of their action and their applications. Crit Rev Biotechnol 35(2): 222-234

Lowery OH, Rosebrough NJ, Fare AL, Randall RJ (1951) Protein measurement with folin phenol reagent. JBioChem 193:265-225
Mauricio J, Millán C, Ortega J (1998) Influence of oxygen on the biosynthesis of cellular fatty acids, sterols and phospholipids during alcoholic fermentation by Saccharomyces cerevisiae and Torulaspora delbrueckii. World J Microbiol Biotechnol 14(3):405-410

McManus CJ, May GE, Spealman P, Shteyman A (2014) Ribosome profiling reveals post-transcriptional buffering of divergent gene expression in yeast. Genome Res 24(3):422-430

Mehlomakulu NN (2015) Genetic investigation and characterization of killer toxins secreted by non-Saccharomyces yeasts. Stellenbosch University, Stellenbosch

Melvydas V, Bružauskaitė I, Gedminienè G, Šiekštelè R (2016) A novel Saccharomyces cerevisiae killer strain secreting the $X$ factor related to killer activity and inhibition of S. cerevisiae K1, K2 and K28 killer toxins. Indian J Microbiol 56(3):335-343

Mohan M, Kozhithodi S, Nayarisseri A, Elyas KK (2018) Screening, purification and characterization of protease inhibitor from Capsicum frutescens. Bioinformation. 14(6):285

Nooralabettu KP. Optimisation of ammonium sulfate precipitation method to achieve high throughput concentration of crude alkaline phosphatase from Brown shrimp (Metapenaeus monoceros) hepatopancreas. Int J Anal Bio-Sci Vol. 2014;2(1).

Silverstein RM, Bassler GC, and Morrill, T. C. Spectrometric identification of organic compounds. 5th ed John Wiley and Sons, Inc USA 1991:419 Pp.

Soares GAM, Sato HH (2000) Characterization of the Saccharomyces cerevisae Y500-4L killer toxin. Braz J Microbiol 31(4):291-297

T.R. S. Organic spectroscopy. Published by S Chand and company LTD New Delhi. 2009: 356

Taguchi S (1995) Communication between protease and protease inhibitor in the Streptomyces world. Actinomycetologica. 9(2):216-227

Valzano M, Cecarini V, Cappelli A, Capone A, Bozic J, Cuccioloni M et al (2016) A yeast strain associated to Anopheles mosquitoes produces a toxin able to kill malaria parasites. Malar J 15(1):21

Villalba ML, Sáez JS, del Monaco S, Lopes CA, Sangorrín MP (2016) TdKT, a new killer toxin produced by Torulaspora delbrueckii effective against wine spoilage yeasts. Int J Food Microbiol 217:94-100

Waema S, Maneesri J, Masniyom P (2009) Isolation and identification of killer yeast from fermented vegetables. Asian Journal of Food and Agro-Industry 2(4):126-134

\section{Publisher's Note}

Springer Nature remains neutral with regard to jurisdictional claims in published maps and institutional affiliations.

\section{Submit your manuscript to a SpringerOpen ${ }^{\circ}$ journal and benefit from:}

- Convenient online submission

- Rigorous peer review

- Open access: articles freely available online

- High visibility within the field

- Retaining the copyright to your article

Submit your next manuscript at $>$ springeropen.com 